\title{
ISLAMIC CENTRE DI ACEH SELATAN (INTANGIBLE METAPHOR)
}

\author{
Islamic Center in Aceh Selatan (Intangible Metaphor)
}

\author{
Mitra Ariansyah ${ }^{1}$, Muhammad Joni $^{2}$ \\ 1)Program Studi Arsitektur, Fakultas Teknik Universitas Muhammadiyah Banda Aceh (mitraariansyah3@gmail.com) \\ 2) Program Studi Arsitektur, Fakultas Teknik Universitas Muhammadiyah Banda Aceh (muhammad.joni.tgc@gmail.com)
}

\begin{abstract}
ABSTRAK
Aceh Selatan termasuk sebagai daerah yang memiliki nilai keislaman yang tinggi, hampir di setiap kampung dan desa/kelurahan memiliki masjid, Majelis Taklim dan Pondok Pesantren. Saat ini jumlah pesantren di Kabupaten Aceh Selatan terdapat 65 Pondok Pesantren dan masjid berjumlah 270 masjid. Maka dari itu perlu hadirnya sebuah pusat kegiatan umat Islam di Aceh Selatan. Islamic Center di Aceh Selatan terletak di Kota Fajar Kecamatan Kluet Utara. Maksud rancangan ini yaitu memberikan pelayanan kepada masyarakat, pemberdayaan dan peningkatan lembaga keagamaan, meningkatkan pengetahuan dan keimanan serta bertujuan mewujudkan wadah pusat pengembangan kegiatan islam di Aceh Selatan yang dapat menunjang kegiatan dalam bidang dakwah, sosial pendidikan, dan kebudayaan. Islamic Center ini berada di tingkat kabupaten di wilayah lokal Kabupaten dan mempunyai masjid bertaraf kabupaten, yaitu masjid agung, yang dilengkapi dengan fasilitas-fasilitas seperti Peribadatan/ibadah, fasilitas mu'amalah dan fasilitas tarbiyah. Lebih banyak berorientasi pada operasional pembangunan dakwah secara langsung. Penerapan tema Intangible Metaphor pada bangunan Islamic Center ini adalah tranformasi dari bentuk tangan ketika berdo'a hingga membentuk block-block bangunan yang berjumlah 10 sesuai dengan jumlah jemari tangan. Tema Intangible Metaphor ini diharapkan bahwa sesuai fungsinya bangunan ini sendiri dapat menjadi media penyedia dan informasi tentang Islamic Center Aceh Selatan. Luas lahan $40.000 \mathrm{~m}^{2}$, luas lantai dasar $9.505 \mathrm{~m}^{2}$, luas lantai keseluruhan $38.020 \mathrm{~m}^{2}$, massa tunggal, dengan kapasitas di dalam bangunan menampung 3000 jamaah, serta di luar bangunan menampung 1000 jamaah. Fasilitas kegiatan utama adalah ruang Ruang Shalat, Kantor Pengelola, Kantor Baziz, Ruang Kelas, Perpustakaan, Mess dan Radio dakwah. Sedangkan penunjang ada Auditorium, Restoran dan pos penjagaan.
\end{abstract}

Kata-kata Kunci : Aceh Selatan, Intangible Metafora, Islamic Center.

\begin{abstract}
South Aceh is included as an area that has a high Islamic value, almost in every village has a mosque and almost in every village / kelurahan there is a Taklim Council and Islamic Boarding School, for now the number of boarding school in South Aceh Regency there are Sixty-five Islamic boarding schools and two mosques. hundred and seventy mosques. Therefore, it is necessary to have a center for Muslim activities in South Aceh. The Islamic Center in South Aceh is located in the City of Fajar, North Kluet District, the purpose of this building is to provide services to the community, empower and improve religious institutions, increase knowledge and faith, aiming at realizing a central container for the development of Islamic activities in South Aceh that can support activities in the fields of da'wah, social education, and culture. The district-level Islamic Center is the Islamic Center which is located in the district's local area and has a districtlevel mosque, namely the grand mosque, which is equipped with facilities such as worship/worship, mu'amalah facilities and tarbiyah facilities. more oriented to the operational development of da'wah directly. The application of the Intangible Metaphor theme in the Islamic Center building transforms from the shape of the hand when praying to forming 10 building blocks according to the number of fingers. The theme of the Intangible Metaphor is expected that according to its function, this building itself can be a media provider and information about the Islamic Center of South Aceh. Land area of $40,000 \mathrm{~m}^{2}$, ground floor area of $9,505 \mathrm{~m}^{2}$, overall floor area of $38,020 \mathrm{~m}^{2}$, single mass, with a capacity inside the building to accommodate 3000 worshipers, and outside the building to accommodate 1000 worshipers. The main activity facilities are Prayer Room, Management Office, Baziz Office, Classroom, Library, Mess and Radio Da'wah. While the support is an auditorium, restaurant and guard post.
\end{abstract}

Key words: Aceh Selatan, Intangible Metafora, Islamic Center.

\begin{tabular}{lll}
\hline Article History & \\
\hline Diterima (Received) & $:$ & $18-06-2021$ \\
Diperbaiki (Revised) & $:$ & $29-06-2021$ \\
Diterima (Accepted) & $:$ & $30-06-2021$
\end{tabular}




\section{PENDAHULUAN}

Aceh Selatan merupakan sebuah kabupaten dari Provonsi Aceh. Sesuai dengan namanya, Aceh Selatan terletak di daerah selatan Aceh. Aceh Selatan berbatasan langsung dengan Samudra Hindia. Luas wilayah Aceh Selatan sekitar $7 \%$ dari luas Provinsi Aceh. Terdiri dari 18 kecamatan mulai dari Labuhan Haji Barat sampai ke Trumon Timur, dan memiliki kira-kira sekitar 250 desa.

Aceh Selatan termasuk sebagai daerah yang memiliki nilai keislaman yang tinggi, dimana hampir di setiap kampung memiliki masjid dan hampir disetiap desa/kelurahan ada majelis taklim dan pondok pesantren, Untuk saat ini jumlah pesantren di Kabupaten Aceh Selatan terdapat 65 pondok pesantren dan masjid berjumlah 270 masjid.

Masjid dimana bermulanya dakwah dikembangkan dan disebarkan oleh para ulama tidak lagi secara keseluruhan mampu menampung kegiatan-kegiatan dakwah, kegiatan tersebut dipindahkan ke luar masjid ke ruang tertentu, gedung, lembaga-lemabaga sendiri dan terbentuk lah komplek-komplek tersendiri, dengan pemahaman yang berbeda tentang ajaran agama islam. Hal tersbut menimbulkan kerenggangan solidaritas antar sesama umat.

Menanggapi permasalahan di atas, maka dari itu perlu hadirnya sebuah pusat kegiatan ummat Islam khususnya Kabupaten Aceh Selatan, guna mendidik pemuda dan anak-anak menjadi generasi Islami. Wadah ini juga penting sebagai pembimbing bagi yang anak muda dan menjadi tempat bagi mereka untuk mendiskusikan problema yang menyangkut tentang islam.

\section{DESKRIPSI LOKASI}

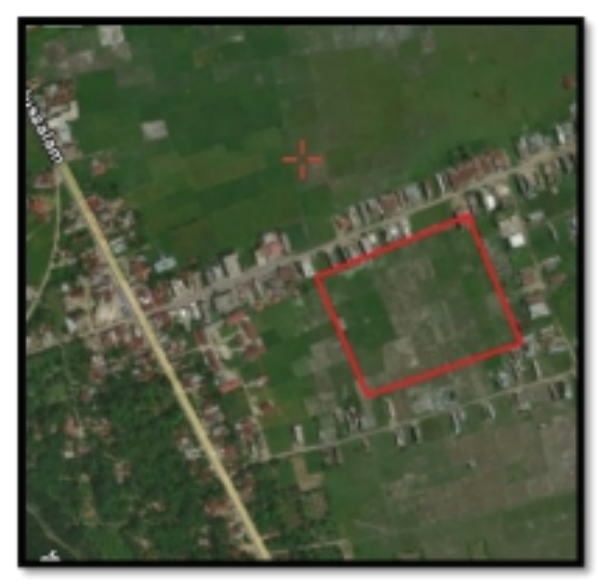

Gambar 1: Lokasi Tapak

Sumber: Analisis, 2019
Islamic Center di Aceh Selatan ini berlokasi di JI. T Meurah Adam, Kec.Kluet Utara, Kab.Aceh Selatan. Luas Lahan untuk rancangan Islamic Center di Aceh Selatan ini adalah Empat (4) Ha $\left(40.000 \mathrm{~m}^{2}\right)$.

\section{STUDI LITERATUR}

Islamic Center Aceh Selatan adalah suatu gedung/tempat sebagai pusat atau sentra informasi keislaman yang terletak di Kabupaten Aceh Selatan.

Islamic Center di Indonesia harus memiliki beberapa persyaratan yang akan berfungsi sebagai control kegiatan. Diantara persyaratan tersebut adalah Islamic Center harus memiliki:

\subsection{Fungsi Islamic Center}

Menurut buku petunjuk pelaksanaan proyek Islamic Center di seluruh Indonesia (1976), Fungsi Islamic Center sebagai suatu lembaga yang mempunyai ruang lingkup yang spesifik dibidang agama dan ilmu, maka pemikiran yang dapat menunjang fungsi suatu Islamic Center adalah sebagai berikut:

a. Tempat Ibadah yaitu fasilitas masjid

b. Sebagai tempat muamalah yatu fasilitas seperti aula, ruang pertemuan dan baitu mall.

c. Sebagai tempat tarbiah dan dakwah yaitu Taman Pendidikan Alqur'an (TPA), Perpustakaan Islam, ruang pelatihan dakwah.

d. Tempat konsultasi dan komunikasi (masalah ekonomi-sosial budaya) kantor pengelola, seperti restoran, ruang foto copy, pusat perbelanjaan souvenir dan auditorium.

\subsection{Tipe/Klasifikasi}

\section{A. Klasifikasi Islamic Center}

Di Indonesia Islamic Center diklasifikasikan menjadi :

a. Islamic Center Tingkat Pusat

Yaitu Islamic Center yang mencakup lingkungan nasional dan mempunyai masjid bertaraf negara, yang dilengkapi dengan fasilitas penelitian dan pengembangan, perpustakaan, museum dan pameran keagamaan, ruang musyawarah besar, ruang rapat dan konferensi, pusat pembinaan kebudayaan dan agama, balai penyuluhan rohani, balai pendidikan dan penelitian Mubaligh, pusat Radio Dakwah dan sebagainya.

b. Islamic Center Tingkat Regional

Yaitu Islamic Center yang mencakup lingkup propinsi dan mempunyai masjid bertaraf propinsi, yaitu masjid raya yang di lengkapi dengan fasilitas 
yang hampir sama dengan tingkat pusat tetapi bertaraf dan berciri regional.

c. Islamic Center Tingkat Kabupaten

Yaitu Islamic Center yang mencakup lingkup lokal Kabupaten dan mempunyai masjid bertaraf kabupaten, yaitu masjid agung, yang dilengkapi dengan fasilitas-fasilitas yang bertaraf lokal dan lebih banyak berorientasi pada operasional pembangunan dakwah secara langsung.

Dari beberapa klasifikasi di atas maka Islamic Center di Aceh Selatan adalah Islamic Center Tingkat Kabupaten dengan syarat harus memiliki masjid Agung yang dilengkapi dengan fasilitasfasilitas yang bertaraf lokal.

\section{B. Klasifikasi Mesjid}

Pihak Departemen Agama (Kementrian agama) mengeluarkan ketentuan untuk memberikan sebutan yang berbeda kepada masjid. Menurut ketentuan itu dan menurut klasifikasi yang ditetapkan oleh Dewan Masjid Indonesia (DMI) (Abu Bakar Ash-shiddiq, 2014).

Berikut ini beberapa masjid yang telah ditetapkan menjadi 7 klasifikasi yakni :

\section{Tabel 1: Klasifikasi Mesjid}

\begin{tabular}{cll}
\hline Tipe A & $\begin{array}{l}\text { Masjid } \\
\text { Negara }\end{array}$ & $\begin{array}{c}\text { Masjid Negara dan } \\
\text { Istiqlal ditetapkan } \\
\text { sebagai satu- } \\
\text { satunya masjid } \\
\text { negara. }\end{array}$ \\
\hline Tipe B & Masjid Akbar & Masjid Nasional. \\
\hline Tipe C & Masjid Raya & Masjid Provinsi \\
\hline Tipe D & Masjid Agung & $\begin{array}{l}\text { Masjid } \\
\text { Kabupaten/Kota. }\end{array}$ \\
\hline Tipe E & Masjid Besar & Masjid Kecamatan. \\
\hline Tipe F & Masjid Jami' & Masjid Kelurahan \\
\hline Tipe G & Masjid Biasa & $\begin{array}{l}\text { Tidak masuk } \\
\text { tingkatan 1-6. Untuk } \\
\end{array}$ \\
\end{tabular}

Sumber : Analisis 2019

Pada rancangan Islamic Center di Aceh Selatan akan menererapkan masjid tipe $D$, yaitu bertaraf masjid agung atau masjid tingkat Kabupaten/Kota.

\section{TEMA PERANCANGAN}

Menurut Jenk (1990), dalam bukunya "The Languange of Phost Modern" Dimana Arsitektur dikaitkan dengan gaya bahasa, antara lain dengan cara metafora. Pengertian Metafora dalam Arsitektur adalah kiasan atau ungkapan bentuk, diwujudkan dalam bangunan dengan harapan akan menimbulkan tanggapan dari orang yang menikmati atau memakai karyanya.

Menurut Snyder dan Cattanese (1979), Metafora dapat diidentifikasikan pola-pola yang mungkin terjadi dari hubungan-hubungan parallel dengan melihat keabstrakannya, berbeda dengan analogi yang melihat secara literal.

Metafora sebagai kode yang ditangkap pada suatu saat oleh pengamat dari suatu obyek yang mengandalkan obyek lain dan bagaimana melihat suatu bangunan sebagai suatu yang lain karena adanya kemiripan (Jenks, 1977).

Broadbent (1995), Transforming: Figure of speech in which a name of description term is transferred to some object different from dan juga menurutnya Metafora pada arsitektur adalah merupakan salah satu metode kreatifitas yang ada dalam desain spectrum perancang.

Klasifikasi Metaphora Menurut Antoniades (1992), metafora arsitektur dapat dibagi ke dalam 3 kategori, yaitu :

a. Metafora abstrak (Intangible Metaphor).

Rancangan arsitektur yang mengacu kepada hal-hal yang bersifat abstrak dan tidak dapat dibendakan, misalnya: sosial, budaya, kondisi manusia. Rancangan arsitektur yang menggunakan metafora ini adalah Nagoya City dan Art Museum karya Kisho Kurokawa yang membawa unsur sejarah dan budaya didalamnya.

b. Metafora konkrit (Tangible Metaphor).

Rancangan arsitektur yang mengacu pada benda-benda nyata dan dapat dirasakan secara visual. Rancangan yang mengguanakan metafara ini adalah stasiun TVG karya Santiago Calatrava yang menerjemahkan bentuk burung terbang kedalam bagunan.

c. Metafora Kombinasi (Combined Metaphor).

Rancangan arsitektur yang memiliki metafora abstrak dan konkrit didalamnya. Rancangan arsitektur yang menggunakan metafora ini adalah EX Plaza Indonesia karya Budiman Hendro Purnomo yang menjadikan gaya kinetic pada sebuah mobil sebagai konsepnya, yang diterjemahkan menjadi gubahan masa lima kotak yang miring sebagai ekspresi gaya kinetic mobil, kolom-kolom penyangganya sebagai ban mobil.

Adapun tema Metafora yang akan diambil dalam perencanaan Islamic Center di Aceh Selatan ini adalah metafora abstrak (Intangible) yaitu Metafora yang mengacu pada hal-hal yang bersifat abstrak dan tidak dapat dibendakan, misalnya: sosial, budaya dan kondisi manusia. 


\section{ANALISIS PERANCANGAN}

\subsection{Analisis Pemakai dan Kegiatan}

Sesuai dengan Pedoman Pelaksanaan Islamic Center di Indonesia, yang dianalisis adalah pengunjung, pengelola, penyewa dan servis Jumlah pemakai dari bangunan Islamic Center ini terdiri dari masyarakat, pengurus/ pengelola serta para pelajar dan santri yang terdapat di Aceh Selatan. Banyaknya jumlah pemakai dapat ditinjau dari jumlah penduduk di Kabupaten Aceh Selatan. Pertahunnya adalah sebagai berikut :

Tabel 2. Jumlah Penduduk

\section{TAHUN JUMLAH PENDUDUK KOTA BANDA ACEH}

\begin{tabular}{ll}
\hline 2008 & 210111 \\
\hline 2009 & 239.404 \\
\hline 2010 & 249.499 \\
\hline 2011 & 207971 \\
\hline 2012 & 212612 \\
\hline 2013 & 216994 \\
\hline 2014 & 220971 \\
\hline 2015 & 224897 \\
\hline 2016 & 228603
\end{tabular}

Sumber: Analisis, 2019

\section{A. Organisasi Ruang}

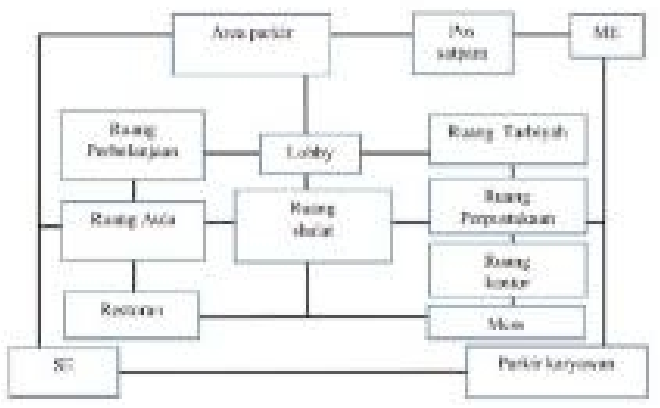

\section{Skema 1. Organisasi Ruang Makro Sumber: Analisis, 2019}

Pada organisasi makro Islamic Centre di Aceh Selatan ini, diatur secara umum dan menjelaskan hubungan antar ruang secara menyeluruh.

\section{B. Besaran Ruang}

Luas keseluruhan bangunan Islamic Centre di Aceh Selatan ini memiliki luasa sebesar $132.321,33 \mathrm{~m}^{2}$ dengan fasilitas telah diuraikan di dalam Tabel 3.
Tabel 3. Rekapitulasi Luas Ruang

Rekapitulasi Besaran Luasan Ruang

\begin{tabular}{|c|c|c|}
\hline No & Kelompok Kegiatan & $\begin{array}{l}\text { Luas Ruang } \\
\qquad\left(\mathrm{m}^{2}\right)\end{array}$ \\
\hline \multirow[t]{2}{*}{1} & Kegiatan Ibadah & \\
\hline & - Fasilitas Masjid & $11.035 \mathrm{~m}^{2}$ \\
\hline \multirow[t]{2}{*}{2} & Kegiatan Muamalah & \\
\hline & $\begin{array}{l}\text { - Fasilitas } \\
\text { perpustakaan } \\
\text { - Fasilitas gedung } \\
\text { serbaguna } \\
\text { - Fasilitas Restoran }\end{array}$ & $\begin{array}{r}265.2 \mathrm{~m}^{2} \\
1.933 \mathrm{~m}^{2} \\
609.28 \mathrm{~m}^{2}\end{array}$ \\
\hline \multirow[t]{2}{*}{3} & Kegiatan Tarbiyah & \\
\hline & $\begin{array}{l}\text { - Fasilitas radio } \\
\text { dakwah } \\
\text { - Fasilitas Ruang } \\
\text { kelas(TPA) }\end{array}$ & $\begin{array}{l}167 \mathrm{~m}^{2} \\
390 \mathrm{~m}^{2}\end{array}$ \\
\hline \multirow[t]{3}{*}{4} & Kegiatan Pengelola & \\
\hline & $\begin{array}{l}\text { - Fasilitas kantor } \\
\text { BAZIS } \\
\text { - Fasilitas kantor } \\
\text { pengelola } \\
\text { - Fasilitas Mess } \\
\text { Putra/putri }\end{array}$ & $\begin{array}{r}181.35 \mathrm{~m}^{2} \\
236.6 \mathrm{~m}^{2} \\
112.648 \mathrm{~m}^{2}\end{array}$ \\
\hline & Total Luasan & $132.321,33 \mathrm{~m}^{2}$ \\
\hline
\end{tabular}

Sumber: Analisis, 2019

\section{Analisis Tapak}

Analisis tapak yang dilakukan adalah kondisi eksisting tapak ,ukuran tapak, potensi tapak, analisis pencapaian, analisis iklim dan analisis view.

\section{Analisis Bangunan}

Analisis bangunan yang dilakukan adalah analisis massa bangunan, analisis bentuk massa bangunan, analisis sirkulasi, analisis struktur kontruksi, dan analisis material.

\section{E. Sistem Utilitas}

Sistem yang mengatur perangkat keras fungsi bangunan seperti; jaringan air bersih dan air kotor, instalasi listrik, instalasi pencegahan dan pemadaman kebakaran, penangkal petir, sistem penghawaan, sistem pengelolaan air limbah (ipal), sistem pengelolaan sampah dan pencahayaan bangunan. 


\section{KONSEP PERANCANGAN}

A. Konsep Sesuai Tema

Dalam proyek Islamic Center ini, metafora yang akan diterapkan pada bangunan adalah metafora yang bersifat Intangible, menggunakan bentuk gerakan tangan mengadah ketika sedang berdo'a yang jika dilihat pada bangunannya berbentuk blok-blok bangunan yang di definisikan sebagai jemari yang berjumlah 10, konsepnya lebih ditekankan pada persepsi apresiator/ masyarakat ketika melihat Islamic Center di Aceh Selatan yang mencerminkan bangunan Islami atau yang berhubungan dengan Pendidikan.

Berdasarkan kesimpulan di atas ada beberapa hal yang dapat diterapkan dalam konsep rancangan, diantaranya:

a. Logika tatanan pada konstruksi yang akan mengembangkan citra secara visual dan selubung fisik yang baik.

b. Menampilkan bentuk yang tidak monoton.

c. Pentingnyan filosofi atau makna yang diekspresikan.

d. Bangunan bermassa tunggal, monumental dan dibuat dominan.

e. Mengguanakan warna-warna alamami dan warna yang menampilkan kesan alami.

\section{B. Konsep Tapak}

a. Penzoningan

Permintakan atau zoning pada tapak dikelompokkan menjadi beberapa bagian didasarkan pada daerah yang memiliki sifat dan kebutuhan yang sama dalam satu kelompok, sehingga diperoleh pengoptimalan dan penyatuan fungsi yang beragam dalam satu tapak. Berdasarkan keterkaitan zona, maka permintakan pada Islamic Cenetr Aceh Selatan sebagai berikut:

1) Zona publik adalah zona yang diperlukan untuk umum, seperti tempat parkir, lobby, gedung serbaguna dan lainnya. Secara umum ruang-ruang yang bersifat publik di tempatkan di bagian depan. Namun, untuk kondisi-kondisi tertentu disesuaikan dengan fungsi dan kegiatan yang ada.

2) Zona semi publik adalah zona yang sifatnya tidak umum, seperti ruang pengelola dan fasilitas Pendidikan

3) Zona privat adalah zona yang sifatnya memiliki privasi yang tinggi, hanya digunakan untuk pemakaian tertentu dan membutuhkan ketenangan yang tinggi, seperti mes.
4) Zona servis pada bangunan meliputi area loading dock/area bongkar muat, dan utilitas.

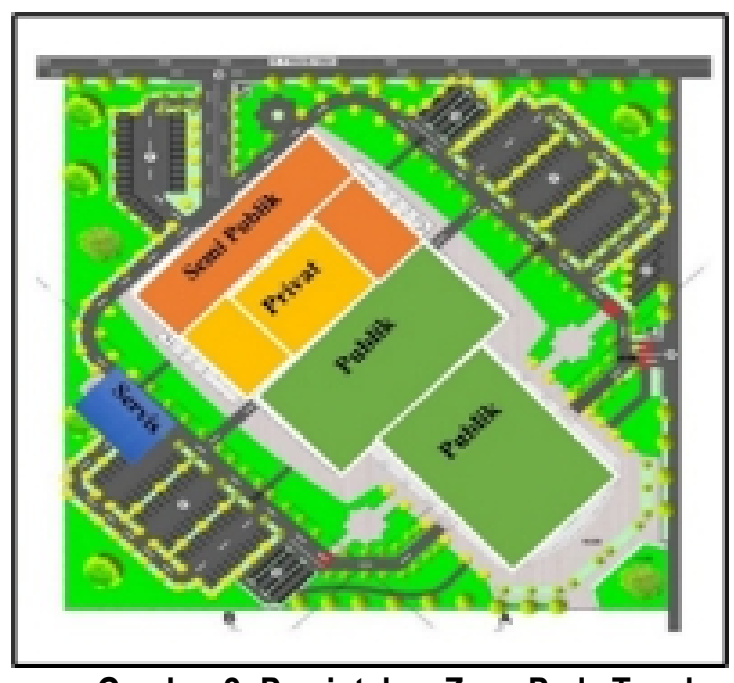

Gambar 2: Pemintakan Zona Pada Tapak Sumber : Analisis, 2019

\section{b. Pencapaian}

Pencapaian ke site dapat dicapai melalui jalur utama yaitu Jl. T Meurah Adam. Pada pencapaian dalam site terdapat pemisahan pencapaian dengan menggunakan kendaraan dengan pencapaian pejalan kaki.

\section{Konsep Tata Hijau (Lanskap)}

Penggunaan Lansekap pada Islamic Center di Aceh selatan ini antara lain adalah sebagai berikut:

a. Tanaman pengarah, yaitu jenis tanaman yang ditempatkan pada jalur masuk dan keluar tapak;

b. Tanaman peneduh, yaitu jenis tanaman yang bertajuk lebar, rindang dan juga tidak menghalangi pandangan sehingga dapat diletakkan sebagai peneduh pada zona parkir dan area terbuka lainnya.

c. Tanaman eksterior, yaitu jenis tanaman penghias dekorasi eksterior bangunan yang ditempatkan pada taman atau pada bagian luar bangunan.

d. Tanaman interior, yaitu jenis tanaman yang berfungsi sebagai penghias dekorasi ruangan dapat juga dapat menyerap racun dan polutan pada ruangan sehingga udara di dalam ruang akan terasa lebih bersih.

\section{Konsep Parkir}

Area parkir yang di rancang pada tapak Islamic Center Aceh Selatan adalah sebagai berikut : 
a. Area parkir untuk pengunjung berada dua sisi pada bagian samping bangunan.

b. Area parkir untuk pengelola dan area parkir servis berada pada bagian belakang bangunan.

Pola bentuk parkir yang direncanakan pada perancangan Islamic Centre ini menggunakan parkir pada umumnya yaitu parkir sudut $45^{\circ}$ dan $90^{\circ}$. Standar Jumlah Parkir untuk bangunan bioskop adalah 1 mobil / $50 \mathrm{~m} 2$ lantai bruto atau 1 tempat parkir untuk tiap 4 tempat duduk atau 1 tempat parkir untuk tiap bangku panjang untuk 4 orang.

\section{E. Konsep Bangunan}

a. Sirkulasi yang digunakan dalam perancangan Islamic Center di Aceh selatan terdiri dari sirkulasi horizontal dan sirkulasi vertikal.

b. Sistem Struktur, struktur utama merupakan struktur yang terdiri dari struktur atas, tengah dan bawah, yang akan menopang beban bangunan.

c. Material struktur menggunakan baja $\mathrm{H}$ (komposit) pada kolom, balok baja I dan struktur rangka bidang untuk bagian atap, material lantai menggunaan kramik, ubin didalam bangunan dan paving block di bagian luar bangunan. dinding menggunakan quipanel dan kaca. Material plafon menggunakan acoustic tile dan PVC.

F. Konsep Utilitas

a. Jaringan Air Bersih

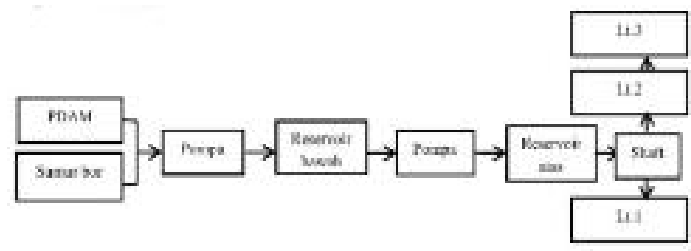

Skema 2. Jaringan Air Bersih

Sumber: Analisis, 2019

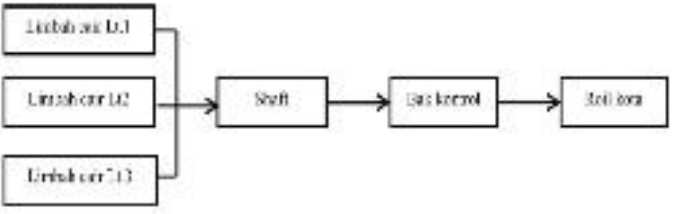

Skema 3. Jaringan Kotoran Cair dan Kotoran Padat

Sumber: Analisis, 2019 b. Jaringan Listrik

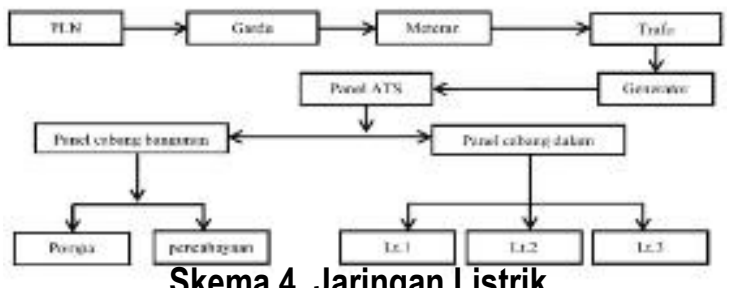

Skema 4. Jaringan Listrik

Sumber: Analisis, 2019

c. Sistem Pengolahan Sampah

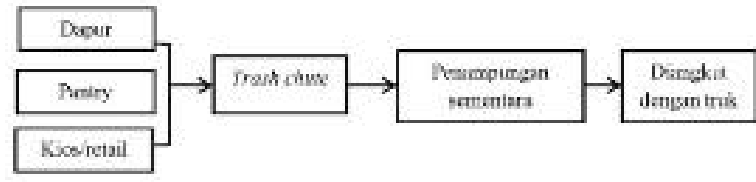

\section{Skema 5. Sistem Pengolahan Sampah}

Sumber: Analisis, 2019

\section{G. Konsep Bentuk}

Konsep bentuk yang pada perancangan Islamic Centre di Aceh Selatan ini, penerapannya berbentuk bidang persegi dan lengkung hal ini berkaitan dengan konsep perancangan yang menerapkan kesan simple atau sederhana pada bangunan.

Transformasi bentuk bangunan Islamic Center di ambil dengan pertimbangan :

a. Bentuk dasar bangunan merupakan bentuk yang terinsfirasi dari graka atau posisi tangan ketika berdo'a.

b. Bentuk bidang simetris yang digunakan merupakan sketsa dari bentuk tangan atau jemari tangan
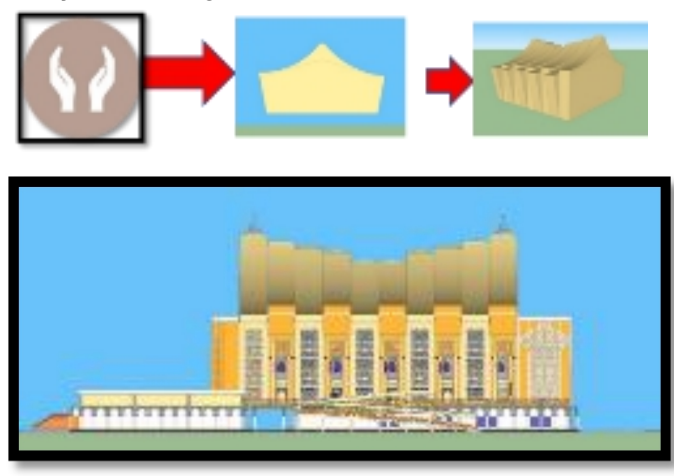

Gambar 3: Konsep Bentuk Sumber: Analisis, 2019 
Rumôh

Journal of Architecture - University of Muhammadiyah Aceh Vol: 11 | No: 1 (2021): June

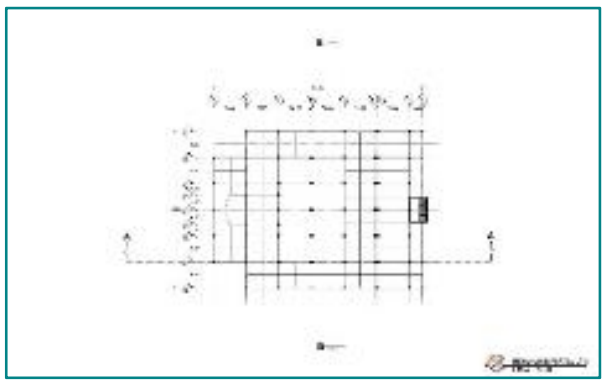

Gambar 10: Denah Lantai 4

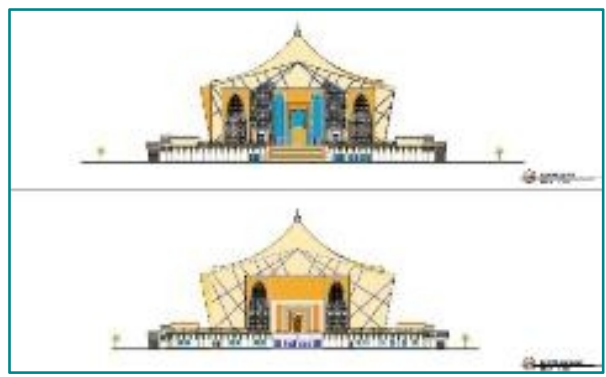

Gambar 11: Tampak depan \&

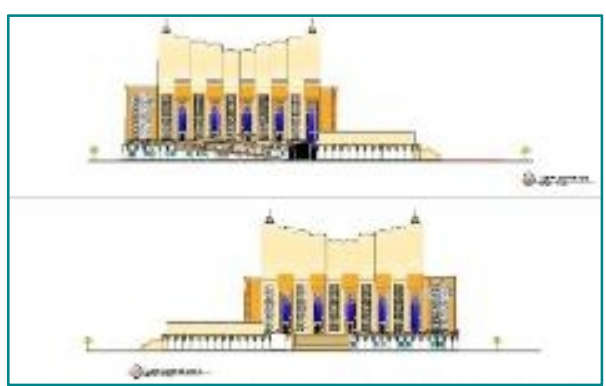

Gambar 12: Tampak samping

Gambar 7: Denah Lantai 1

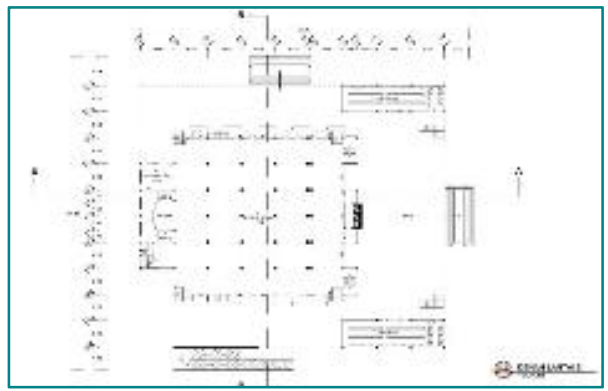

Gambar 8: Denah Lantai 2

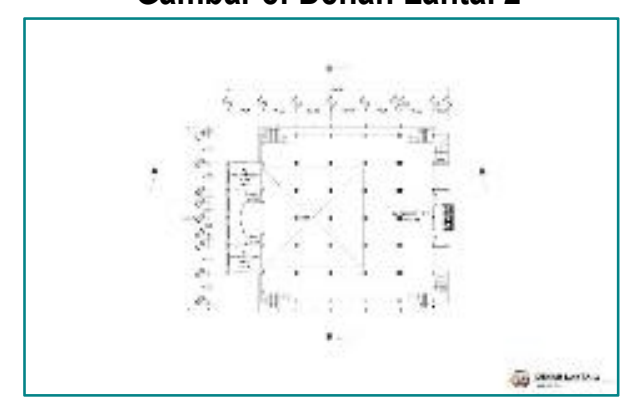

Gambar 9: Denah Lantai 3

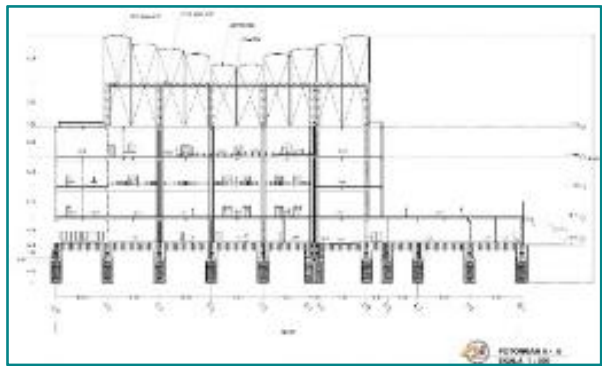

Gambar 13: Potongan A-A

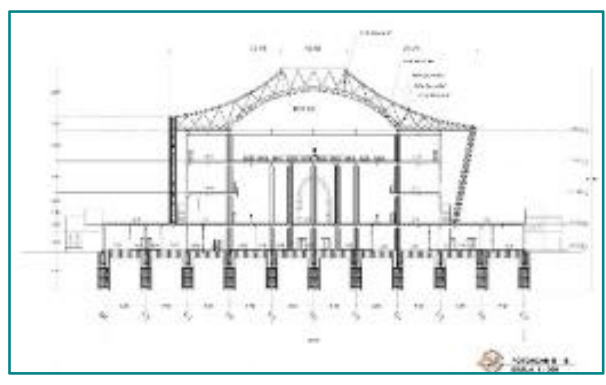

Gambar 14: Potongan B-B 


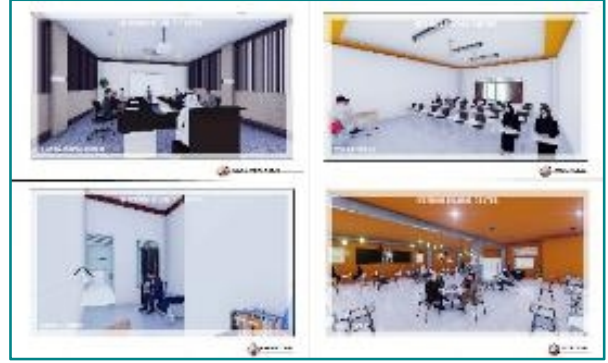

Gambar 15: Suasana Interior

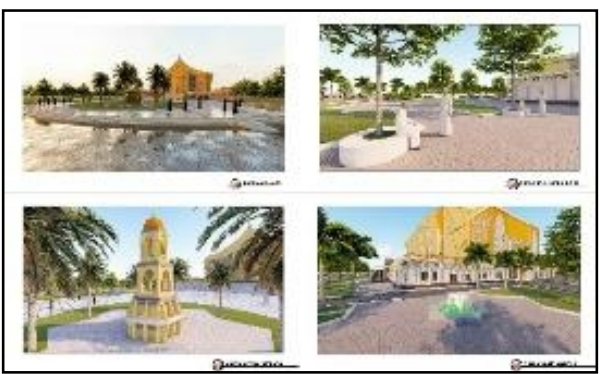

Gambar 16: Suasana Exterior

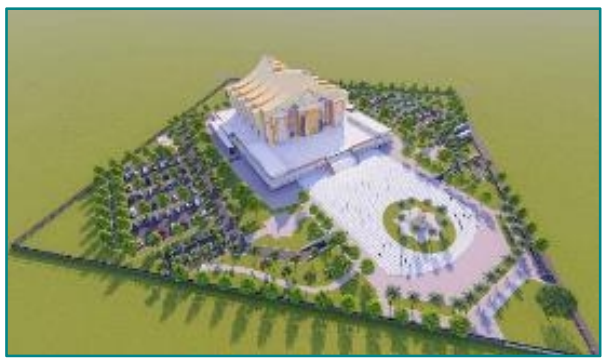

Gambar 17: Perspektif Kawasan

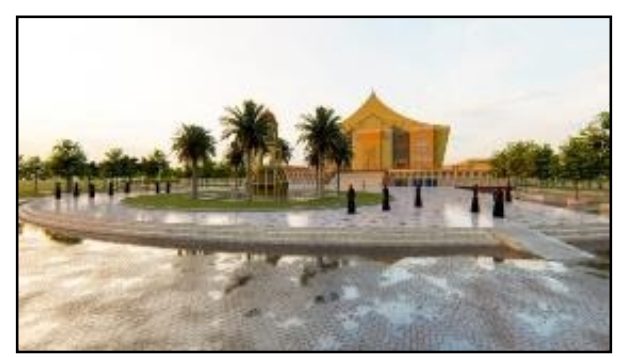

Gambar 18: Perspektif Suasana

\section{Daftar Pustaka}

Le Corbusier. (1927). Toward an Architecture.

James C. Snyder, Anthony J. Catanesse, (1979)" "Introduction to Architecture

Prodi Arsitektur Unmuha. (2013). Buku Panduanm Program Studi Teknik Arsitektur, Fakultas Teknik Universitas Muhammadiyah Aceh.

Depertemen Agama RI. (1976). Buku Petunjuk Pelaksanaan Proyek Islamic Center di Seluruh Indonesia, Direktorat Jendral Bimbingan Masyarakat Islam.

Hanabawi M. (2015). Islamic Center Aceh Jaya, Laporan Buku Studio Tugas Akhir. Program Studi Teknik Arsitektur, Fakultas Teknik
Universitas Muhammadiyah Aceh, Banda Aceh.

Jencks. C (1990."Languange of Post-Modern Architecture

Rencana Tata Ruang Wilayah (RTRW) 2009 2029. Kota banda Aceh No.4 tahun, 2009,

Dalam Kamus Besar Bahasa Indonesia. 1991. Balai Pustaka, Jakarta,

Neufert, Ernst, Data Arsitek, jilid 1 \& 2, edisi kedua, Erlangga Jakarta, 1996.

Badan Pusat Statistik Kabupaten Aceh Selatan. (2017). Jumlah Penduduk per $\mathrm{Km}^{2}$, Mukim, Desa dan Rumah Tangga Di Kabupaten Aceh Selatan.

Website :

http://www.pendis.kemenag.go.id, 10 September 2018; 01.15 wib.

http://simas.kemenag.go.id/index.php/profil/masjid /page/260/?kabupaten_id, 09 September 2018; 01.45 wib.

https://www.masjidabubakargca.com/2014/11/seb utan-tingkatan-dan-klasifikasi.html, 05 Juli 2018; 20.30 Wib).

http://perkembanganarsitekturdunia.blogspot.com/ 2013/01/arsitektur-metafora.html. 30 Juni 2018; 15 : 20 Wib.

https://studylibid.com/doc/726103/bab-ii-tinjauanobjek-rancangan-a.-pengertian-judul-, 27 September 2018; 15.20 Wib.

https://petatematikindo.wordpress.com/2013/04/2 1/administrasi-kabupaten-aceh-selatan/10 September 2018; $20: 23$ Wib

Google Earth, 2017. 10 September 2018; 20 : 55 Wib

\begin{tabular}{l}
\hline Kutipan Artikel \\
\hline Ariansyah, M., Joni. M. (2021). Islamic Centre di \\
Aceh Selatan (Intangible Metaphor), Rumoh,11 \\
(1), 32-39: Juni. DOI: \\
http://doi.org/10.37598/rumoh.v1111.138
\end{tabular}

